\title{
OBRAZ KAPLANA-DUSZPASTERZA W NAUCZANIU ŚW. GRZEGORZA Z NAZJANZU
}

Grzegorz Teolog już podczas pobytu na studiach w Atenach odkrył w sobie powołanie do życia kontemplacyjnego. Pragnął więc zostać mnichem i całkowicie poświęcić się służbie Bożej ${ }^{1}$. W latach 357-358 przebywał nawet w pustelni nad rzeką Irys w Poncie. Ostatecznie jednak ze względu na sytuację rodzinną wrócił do Nazjanzu. Tu zachęcony przez własnego ojca, starego biskupa Nazjanzu, przy poparciu wspólnoty wiernych, prawdopodobnie w Boże Narodzenie 361 r., przyjął sakrament kapłaństwa ${ }^{2}$. Do święceń przystąpił z ogromną niechęcią, czując się nawet przymuszonym. Taki wniosek można wyciagnąc $\mathrm{z}$ analizy wypowiedzi biskupa Nazjanzu. W swoim poemacie autobiograficznym wyznał:

„Ojciec, choć dobrze znał moje zamiary,

nie wiem dlaczego, może być z ojcowskiej,

miłości - straszna ta miłość, gdy z władzą! -

chcąc mię więzami wstrzymać duchowymi

i uczcić tym, co sam miał najlepszego,

gwałtem mię zgina, bym zajął tron drugi.

Tak mi boleść zadał tą tyranią

- inaczej tego nazwać nie potrafię"’.

${ }^{*}$ Ks. dr hab. Paweł Wygralak, prof. UAM - profesor nadzwyczajny w Zakładzie Teologii Patrystycznej i Historii Kościoła na Wydziale Teologicznym Uniwersytetu im. Adama Mickiewicza w Poznaniu; e-mail: pawelwyg@amu.edu.pl.

${ }^{1} \mathrm{~W}$ poemacie autobiograficznym (De vita sua [= Carmina II 1, 11] 1, 292-295, PG 37, 10491050, thum. T. Sinko: Poemat autobiograficzny, w: J.M. Szymusiak, Grzegorz Teolog. U źródet chrześcijańskiej myśli IV wieku, Poznań 1965, 475) Grzegorz zwierzał się: „Ceniłem bardziej Eljasza Tezbitę / i wielki Karmel lub niezwykłe jadło, / pustynne mienie Poprzednika Chrystusa / i Jonadaba synów proste życie".

2 Por. Szymusiak, Grzegorz Teolog, s. 119-121.

${ }^{3}$ Gregorius Nazianzenus, De vita sua (= Carmina II 1, 11) 1, 339-346, PG 37, 1053, thum. Sinko, s. 476. Por. tenże, Epistula 8 (do Bazylego); w liście tym Grzegorz zwierza się swemu przyjacielowi: „Pojmano więc i ciebie, podobnie jak i mnie! Zniewolono nas do przyjęcia godności prezbitera! A przecież nie do tegośmy dążyli!” (PG 37, 33-34, tłum. J. Stahr, POK 15, Poznań 1933, 14-15). Zob. tenże, Oratio 18, 37; w tym kazaniu, które Grzegorz wygłosił na pogrzebie swego ojca, z wyrzutem wspominał wydarzenia sprzed lat: „I nie wiem, w jaki sposób dałem się przez was 
Wypowiedzi Grzegorza sugerują, iż nie chciał przyjąć kapłaństwa ze względu na lęk przed jego wielkością, jak również odpowiedzialnością, która ciąży na każdym kapłanie. Był przekonany, że kierowanie duszami jest „sztuką nad

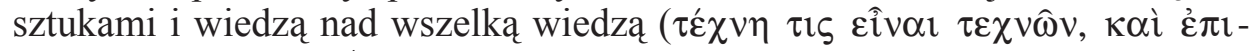
$\sigma \tau \eta \mu \eta \dot{\varepsilon} \pi(\sigma \tau \eta \mu \hat{\omega} v)^{\prime \prime}$. Rodziły się w nim bowiem poważne wątpliwości, czy sprosta tak odpowiedzialnemu wezwaniu.

Staje więc przed nami Grzegorz Teolog jako człowiek, kapłan, który dokonał głębokiej refleksji nad kapłaństwem. Doskonale zdawał sobie sprawę z ogromnej odpowiedzialności, której musi sprostać każdy kapłan posługujący w duszpasterstwie. Grzegorz do tematu kapłaństwa w swojej twórczości wracał wielokrotnie. Jego wypowiedzi pozostają aktualne po dziś dzień i mogą służyć pomocą w formacji seminaryjnej i kapłańskiej.

W niniejszym artykule pragniemy na podstawie mów, jak również utworów poetyckich biskupa Nazjanzu, przybliżyć jego przemyślenia na temat wymagań, którym powinien sprostać każdy duszpasterz ${ }^{5}$. Najpierw przedstawimy wskazania Grzegorza na temat formacji duchowej kapłana, następnie omówimy jego wskazania dotyczące umiejętności głoszenia słowa Bożego i przewodzenia wiernym w ich codziennym życiu. Przedstawimy również zagrożenia, które - zdaniem biskupa Nazjanzu - czyhają na kapłanów w ich duszpasterskim posługiwaniu.

1. Postawa duchowa kapłana. Grzegorz wskazuje na wielkość powołania do kapłaństwa. Swoim słuchaczom uświadamia, że każdy kapłan jest

wyprowadzić na to nieznośne, pełne krętactw, targowisko dusz pod zasłoną zaszczytnego tytułu kapłana" (PG 35, 1035-1036, thum. J.M. Szymusiak, w: tenże, Grzegorz Teolog, s. 342).

${ }^{4}$ Gregorius Nazianzenus, Oratio 2, 16, PG 35, 425, thum. Szymusiak, s. 262. Por. P. Wygralak, Grzegorza z Nazjanzu wizja kaptaństwa. Wprowadzenie do mowy: „Własna apologia po powrocie z Pontu i rozprawa o kaplaństwie”, TPatr 11 (2014) 146-147. Sentencja, że kierowanie duszami jest „sztuką nad sztukami i wiedzą nad wszelką wiedzą” jest powszechnie znana dzięki Grzegorzowi Wielkiemu, który umieści ją w swoim dziele Księga Reguły Pasterskiej. Biskup Rzymu skorzystał prawdopodobnie z przekładu dzieł Grzegorza z Nazjanzu autorstwa Rufina z Akwilei. Por. Grzegorz Wielki, Księga reguly pasterskiej, thum. E. Szwarcenberg-Czerny, ŹM 30, Tyniec - Kraków 2003, 49, nota 1.

${ }^{5}$ Więcej na temat nauczania Grzegorza z Nazjanzu o posłudze kapłańskiej znaleźć można w nastepujących opracowaniach: M. Serra, La carità pastorale in S. Gregorio Nazianzeno, OCP 21 (1955) 337-374; M. Jourjon, Le sacerdoce d'aprés l',, Oratio Secunda” de saint Grégoire de Nazianze, „Bulletin du Comité des Etudes. Compagnie de Saint-Sulpice” 38-39 (1962) 375-383; P.G. Alvés Sousa, El sacerdocio permanente en la „Oratio II, Apologetica” de San Gregorio Nacianceno, w: Escritos sobre el carácter sacerdotal, Teología del Sacerdocio 6, Burgos 1974, 25-41; J. Bernardi, Saint Grégoire de Nazianze observateur du milieu ecclésiastique et théoricien de la fonction sacerdotale, w: Migne et le renouveau des études patristiques,éd. A. Mandouze, Paris 1985, 349-357; A. de Halleux, Grégoire de Nazianze témoin du caractère sacerdotal?, w: Festschrift J. Gribomont, Roma 1988, 331-347; F. Trisoglio, Il pastore d'anima in San Gregorio di Nazianzo, „Renovatio” 25 (1990) 509-527; 26 (1991) 11-36, 185-212, 345-271; 27 (1992) 11-18; F. Gaurier, La retraite et le sacerdoce chez Grégoire de Nazianze, Turnhout 2002. 
powiernikiem Prawdy, który staje w jednym szeregu z aniołami. Kapłan wychwala Boga wraz z archaniołami i składa na ołtarzu ofiary; kapłan dzieli urząd kapłański z samym Chrystusem. Ma on również odnawiać w człowieku obraz Boży, ma przygotować powierzonych sobie wiernych do wejścia do niebiańskiego świata. Kapłan ma również - co Grzegorz bardzo mocno podkreśla - „stać się bogiem oraz innych doprowadzić do boskości”“. Skoro tak wielką godnością zostaje obdarzony człowiek wraz z otrzymaniem święceń kapłańskich, to musi przyjąć je z całą rozwaga, poczuciem odpowiedzialności, a nade wszystko z absolutną pewnością o prawdziwości Bożego powołania.

Grzegorz miał to szczęście, że otaczali go gorliwi kapłani, spośród których ważne miejsce zajmował jego ojciec. To m.in. jego postawa ukształtowała w nim tak odpowiedzialne podejście do kapłaństwa. W mowie pogrzebowej na cześć swego ojca Grzegorz wspomniał o początkach jego kapłaństwa. Podkreślił, że ojciec przyjął misję kapłana, ale uczynił to rozważnie, refleksyjnie, bez żadnego pośpiechu. Uczynił to, jak mówił Kapadocczyk,

„aby przeżyć najpierw swoje oczyszczenie i nabrać doświadczenia i mocy dla oczyszczania innych. Taka jest bowiem zasada w porządku duchowym. Ale z chwilą gdy tę misję przejmuję, łaska zaczyna promieniować - jak prawdziwa łaska od Boga, nie zaś od ludzi, ani - jak mówi Eklezjasta - jak gdyby we własnym zapale i z inicjatywy własnego ducha (por. Koh 1, 17, LXX)"”.

Staje więc ojciec Grzegorza jako przykład w pełni odpowiedzialnego podjęcia kapłańskiej posługi. Zdaniem kaznodziei potrzeba więc, aby każdy, kto jest pewien swego kapłańskiego powołania, nie spieszył się z jego realizacją, ale najpierw dobrze przygotował się przede wszystkim w sferze duchowej. Biskup Nazjanzu przedstawia wiele argumentów przeciwko pośpiechowi w podejmowaniu funkcji kapłańskich. Sięga m.in. do przypowieści Jezusa o ziarnie (por. Mt 13, 5; Łk 8, 6), które rzucone na skalisty grunt - owszem - wzeszło, ale na skutek ostrych promieni słońca zaraz uschło, gdyż nie miało korzenia ${ }^{8}$. Przekaz Grzegorza jest tu nad wyraz oczywisty: aby spełniać obowiązki kapłańskie, trzeba być zakorzenionym w Chrystusie, prowadzić głębokie życie duchowe. Dla owocnego duszpasterzowania potrzeba też nabrać doświadczenia. Z kontekstu wypowiedzi naszego autora wynika, że nie chodzi tu jedynie o doświadczenie duszpasterskie. W pierwszym rzędzie chodzi raczej o doświadczenie w pracy nad sobą. Dzięki temu doświadczeniu bowiem kapłan może prowadzić innych do Boga. To dlatego sam Grzegorz tak bardzo bał się podjąć obowiązki duszpasterza. Nie czuł się do nich w pełni przygotowany, gdyż nie oczyścił jeszcze - jak sam to wyznaje - swojej duszy ${ }^{9}$, tzn. nie podjął wystarczająco skutecznej

\footnotetext{
${ }^{6}$ Gregorius Nazianzenus, Oratio 2, 73, PG 35, 481, tłum. Szymusiak, s. 279.

${ }^{7}$ Tenże, Oratio 18, 15, PG 35, 1004, tłum. Szymusiak, s. 330.

${ }^{8}$ Por. tenże, Oratio 2, 72, PG 35, 480. Zob. F. Villagómez, El sacerdocio en la Oratio II de Gregorio Nacianceno, „Ecclesia” 26 (2012) fasc.2, 187.

${ }^{9}$ Por. Gregorius Nazianzenus, Oratio 2, 78, PG 35, 484-485.
} 
walki z grzechem. To pierwszy istotny element duchowej formacji. Nie może bowiem wspierać innych w walce ze złem ten, kto sam w trosce o czystość własnej duszy nie podjął takiej walki. Ponadto - zdaniem Grzegorza - należy:

„samemu nabrać mądrości, by innym jej udzielać; stać się światłością, by oświecać; zbliżyć się do Boga, by innych do Niego przybliżać; uświęcić się, by uświęcać; za rękę prowadzić i mądrych rad udzielać"10.

Poziom wymagań postawionych tu duszpasterzowi jest wysoki. Musiał on nabyć mądrości, być światłością, trwać blisko Boga, uświęcić się, a także nauczyć się prowadzić powierzonych sobie ludzi. Mówiąc o mądrości Grzegorz najprawdopodobniej myślał nie tyle o wiedzy nabytej, wyuczonej, ale raczej o mądrości jako darze, który człowiek otrzymuje trwając w zażyłym kontakcie z Bogiem. Konieczne jest więc nieustanne pogłębianie relacji z Bogiem. Dokonuje się to przez praktykowanie kontemplacji. Dzięki niej kapłan ma szansę stać się „domem Boga żywego" "11. Dopiero wówczas kapłan oświecony łaską Chrystusa, może stawać się światłością oświecającą innym drogę do Boga. Na drodze kapłańskiego posługiwania istotne jest również pragnienie świętości. Tylko ten, kto jej pragnie, uczyni wszystko, by stała się jego udziałem. Tylko taki kapłan jest na tyle przekonujący, mądry i doświadczony, aby innych wziąć, jak dziecko, za rękę i poprowadzić do Boga.

W formacji duchowej ważne jest dążenie do postawy całkowitego zaufania Chrystusowi i powierzenia Mu swego życia. Jasno wyraził to Grzegorz w swoim poetyckim utworze $O$ rozmaitych rodzajach życia:

„Dla Niego tylko żyje radośnie, dla Niego

odrywa myśl od ziemi i wznosi w górę. [...]

lecz umysł czystą myślą wciąż uszlachetniając,

już nawet do niebieskiej Trójcy się przybliża,

której obraz w swym sercu wyrył był głęboko,

wiedząc jedyną chwałę w trzech światła pięknościach"12.

Jedynie kapłan pełen Chrystusowego ducha staje się Jego świadkiem. Dla biskupa Nazjanzu jest więc oczywiste, że każdy duszpasterz, jeśli kapłaństwo traktuje odpowiedzialnie, musi wyróżniać się głębią swego zjednoczenia z Bogiem. Do realizacji kapłańskiego powołania nie wystarczy, że duszpasterz nie popełnia grzechu.

„Nie wystarczy być bez grzechu temu, który otrzymał takie posłannictwo większość bowiem ludzi, nawet z pospólstwa, brzydzi się grzechem - ale powinien się wyróżniać cnotą w myśl przykazania zawartego w Piśmie: «unikaj

${ }^{10}$ Tamże 2, 71, PG 35, 480, tłum. Szymusiak, s. 279.

${ }^{11}$ Tamże 2, 97, PG 35, 500, tłum. Szymusiak, s. 285.

${ }_{12}$ Tenże, Carmina de se ipso 17: De diversis vitae generibus (= Carmina II 1, 17), 25-26 i 3538, PG 37, 1263-1264, thum. Szymusiak, s. 514. 
grzechu i czyń dobro» (Ps 36, 27). Nie wystarczy to, że zatrze w duszy ślad zła, musi jeszcze ją ozdobić dobrem, aby raczej cnotami przodował niż godnością się wywyższał; nie powinien znać granic $\mathrm{w}$ cnocie ani $\mathrm{w}$ dążeniu do doskonałości"13.

Kapłan musi przede wszystkim praktykować cnoty, wyróżniać się spośród wiernych. Powinien wypełniać to wszystko do czego zachęca św. Paweł w Pierwszym Liście do Tymoteusza (3, 2-3), a więc ma być roztropny, wstrzemięźliwy, nienadużywający wina, w całym swoim postępowaniu nienaganny ${ }^{14}$. Nie powinien nigdy przerwać swojej duchowej formacji ani poczytywać sobie za zysk tego wszystkiego, co udało mu się osiagnąć. Biskup Nazjanzu uważa, że raczej należy żałować tego wszystkiego, czego nie udało się osiągnąć $^{15}$. Tylko wówczas kapłan będzie godny do wypełnienia owocnie swojej misji, tylko wówczas będzie wolny od troski o ziemskie bogactwa, zaszczyty, ludzką sławę ${ }^{16}$. Dla Grzegorza jest też ważne, aby każdy duszpasterz realizował zalecenia sformułowane przez Jezusa w odniesieniu do uczniów wysłanych na głoszenie Dobrej Nowiny. Powinni oni być bezinteresowni i roztropni, a przede wszystkim uduchowieni tak, aby głoszone słowo Ewangelii łączyło się ze świadectwem codziennego życia ${ }^{17}$. W ten sposób została podkreślona waga duchowości każdego kapłana. To dzięki niej głoszone słowo będzie brzmiało autentycznie w ustach apostoła. Nie będzie pustym dźwiękiem, ale głosem świadka.

2. Odpowiedzialność za głoszenie Bożego słowa. Obowiązkiem każdego duszpasterza, co podkreślał wyraźnie już św. Paweł (por. 1Tm 3, 2), jest nauczanie $^{18}$. Do posługi tej Grzegorz podchodzi z charakterystyczną dla siebie odpowiedzialnością. Wszak chodzi o „ocalenie zagrożonej cennej duszy nieśmiertelnej" ${ }^{19}$. To bardzo ważne sformułowanie. Każdy kapłan podejmując jakąkolwiek pracę duszpasterską musi zdawać sobie sprawę, że chodzi o zbawienie człowieka, o jego życie wieczne. Głoszenie Ewangelii jest wskazywaniem wiernym drogi o do nieba.

Nie można owocnie głosić prawd Bożych bez głębokiego życia duchowego $^{20}$. Tylko pasterz zakorzeniony $\mathrm{w}$ Bogu potrafi powierzyć Mu swoje

${ }^{13}$ Tenże, Oratio 2, 14, PG 35, 424, thum. Szymusiak, s. 261. Por. Wygralak, Grzegorza z Nazjanzu wizja kaplaństwa, s. 149.

${ }^{14}$ Por. Gregorius Nazianzenus, Oratio 2, 69, PG 35, 477. Zob. Villagómez, El sacerdocio en la Oratio II de Gregorio Nacianceno, s. 182.

${ }^{15}$ Por. Gregorius Nazianzenus, Oratio 2, 14, PG 35, 424.

${ }^{16}$ Por. tenże, Carmina de se ipso 17: De diversis vitae generibus (Carmina II 1, 17), 29-30, PG 37, 1263.

${ }^{17}$ Por. tenże, Oratio 2, 69, PG 35, 477.

${ }^{18}$ Por. tamże.

${ }^{19}$ Tamże 2, 28, PG 35, 437, tłum. Szymusiak, s. 265.

${ }^{20}$ Por. tamże 2, 35, PG 35, 444. 
posłannictwo. Zdaje sobie bowiem sprawę, że bez Bożej pomocy nic uczynić nie może. Tym bardziej Boża pomoc jest konieczna, że wielokrotnie kapłan musi stanąć do walki z prawdziwym nieprzyjacielem człowieka, z szatanem ${ }^{21}$. Oprócz głębokiej wiary i ufności w Bożą pomoc, pasterz powinien posiadać odpowiednią wiedzę. Biskup Nazjanzu szczegółowo określa zakres niezbędnej wiedzy dobrze przygotowanego duszpasterza. Tak więc powinien być on biegły - używając współczesnych określeń - w filozofii ${ }^{22}$, teologii biblijnej oraz teologii dogmatycznej, szczególnie w trynitologii ${ }^{23}$. Wiązało się to z sytuacją ówczesnego chrześcijaństwa, rozrywanego przez błędne nauczanie ${ }^{24}$. Każdy podejmujący się nauczania wiernych musi być świadomy, że problem w dotarciu do słuchaczy z nauką tkwi najczęściej w niedostatecznym przygotowaniu duchowym i intelektualnym głosiciela słowa Bożego, w jego nieumiejętności przekazywania treści wiary, ale także w niewłaściwym nastawieniu słuchaczy ${ }^{25}$. Dla Grzegorza ważna jest też postawa pokory nauczyciela wiary ${ }^{26}$. Powinien on z jednej strony ciągle pogłębiać swoją więź z Bogiem oraz wiedzę, $\mathrm{z}$ drugiej zaś uznać - w pokorze serca - swoją niemoc w poznawaniu Bożych misteriów ${ }^{27}$. Ponadto konieczna jest znajomość adresatów duszpasterskiego posługiwania.

„Albowiem inna jest mentalność oraz inne reakcje kobiety i mężczyzny, starca i młodzieńca, nędzarza i bogacza, optymisty i pesymisty, człowieka chorego i człowieka zdrowego; inaczej reagują władca i poddany, inteligent i prostak, człowiek odważny i tchórz, złośliwiec i mąż pogodny, człowiek stały i człowiek zmienny"28.

„[Inaczej trzeba się odnosić] do mieszczan i do ludzi ze wsi, inaczej do ludzi prostych, a inaczej do przebiegłych, inaczej do ludzi czynu, a inaczej do spokojnych, inaczej do ludzi ciężkim losem dotkniętych, a inaczej do ludzi szczę́liwych, którzy niepowodzenia nie znają"29.

Kapłan musi być więc świadomy do kogo kieruje słowo Boże. Tu tkwi - zdaniem biskupa Nazjanzu - kolejna trudność i jednocześnie odpowiedzialność

\footnotetext{
${ }^{21}$ Por. tamże 2, 21, PG 25, 429.

${ }^{22}$ Należy pamiętać, że termin ,filozofia” może oznaczać także studia, rozmyślanie, ale również życie zmierzające do bliskości z Bogiem. Por. Szymusiak, Grzegorz Teolog, s. 113.

${ }^{23}$ Por. Gregorius Nazianzenus, Oratio 2, 36, PG 35, 444, tłum. Szymusiak, s. 267: „Wreszcie najważniejszy punkt: trzeba orientować się w nauce o suwerennej i błogosławionej Trójcy. A niebezpieczeństwo dla tego, który ma innych oświecać, jest poważne".

${ }^{24}$ Por. tamże 2, 36-37, PG 35, 444-446.

${ }^{25}$ Por. tamże 2, 39, PG 35, 448.

${ }^{26}$ Por. tenże, Oratio 32, 19, PG 36, 196.

${ }^{27}$ Por. tamże 32, 21, PG 36, 197.

${ }^{28}$ Tenże, Oratio 2, 28, PG 35, 437, tłum. Szymusiak, s. 265.

${ }^{29}$ Tamże 2, 29, PG 35, 437, tłum. Szymusiak, s. 266.
} 
posługi słowa. Jak przemawiać do tak różnych odbiorców? ${ }^{30}$; jakich słów użyć, aby prawda Ewangelii znalazło podatny grunt?; jakie zagadnienia należy omawiać, aby słuchacze skorzystali z głoszonej Bożej prawdy w codziennym postępowaniu? Te pytania i wątpliwości powinny niepokoić serce i myśli roztropnego i pokornego duszpasterza, któremu prawdziwie zależy na zbawieniu powierzonych sobie dusz. Propozycja Grzegorza jest ponadczasowa. Podkreśla on, że nie można uprawiać duszpasterstwa masowego, ale należy indywidualnie podejść do każdego człowieka, uznając jego jednostkowość ${ }^{31}$. Podobnie jak nie wszyscy spożywają te same pokarmy ze względu na wiek czy stan zdrowia, tak też nie wszyscy są jednakowo przygotowani do przyjęcia głoszonej nauki. Należy zatem dostosować sposób głoszenia słowa do możliwości i potrzeba słuchaczy ${ }^{32}$. W tym punkcie schodzą się również metody podejścia do człowieka lekarza i duszpasterza. Obaj muszą stosować metody odpowiednie do stanu ,pacjenta”. Lekarz zastosuje odpowiednią kurację, przepisze właściwe lekarstwa. W przypadku choroby duszy, kapłan także użyje różnych metod głoszenia słowa, różnego słownictwa. Biskup Nazjanzu stara się je wyszczególnić i omówić. Mogą to więc być:

- odpowiednie słowa,

- wskazanie przykładów (chodzi najprawdopodobniej o przykłady z życia świętych, szczególnie postaci znanych z Pisma Świętego),

- zachęty lub przestrogi,

- pochwały i pocieszenia,

- nagany (publiczne lub w ,cztery oczy”),

- pobłażliwość, ustępstwo,

- wymaganie $^{33}$.

Wszystkie te metody pracy z wiernymi powinny, odpowiednio zastosowane, przynieść oczekiwane owoce. Jednak żaden duszpasterz nie może być pewien osiagnięcia sukcesu. Grzegorz używa tu bardzo barwnego porównania. Mówi, że duszpasterzowanie podobne jest do występu linoskoczka, dla którego każde nadmierne przechylenie może okazać się niebezpieczne. Podobnie ma się rzecz z posługą kapłana:

„Niech się przechyli w jakąkolwiek stronę, czy to przez własne złe postępowanie, czy to z braku kompetencji, natychmiast grozi mu niebezpieczeństwo popełnienia błędu i wprowadzenia innych w błąd"34.

Tak więc - zdaniem Grzegorza - w posłudze prowadzenia wiernych ważny jest tak przykład własnego życia, jak i posiadane kompetencje, czyli wiedza

\footnotetext{
${ }^{30}$ Por. Villagómez, El sacerdocio en la Oratio II de Gregorio Nacianceno, s. 194-195.

${ }^{31}$ Por. Szymusiak, Grzegorz Teolog, s. 121.

${ }^{32}$ Por. Gregorius Nazianzenus, Oratio 32, 33, PG 36, 212.

${ }^{33}$ Por. tenże, Oratio 2, 30-33, PG 35, 437-441.

${ }^{34}$ Tamże 2, 34, PG 35, 441, tłum. Szymusiak, s. 267.
} 
oraz doświadczenie duszpasterskie. Wspaniałym przykładem takiej posługi jest m.in. działalność św. Pawła ${ }^{35}$, a także biskupa Aleksandrii Atanazego. Kapadocczyk widział w Atanazym wzór duszpasterza, który potrafił „przekonującym słowem” pogodzić wszystkich skłóconych, troszczyć się zarówno o swoich zwolenników, jak i przeciwników, by ostatecznie zdobyć „sobie wszystkie serca"36.

Ważną cechą głosiciela Ewangelii jest również cierpliwość wobec powierzonych mu wiernych. Najlepszym wzorem jest Chrystus, który nieustannie okazuje człowiekowi swoje miłosierdzie. Trzeba więc dawać szansę człowiekowi, który w swoim oporze nie zawsze jest gotowy od razu przyjąć słowa Ewangelii. Należy podejmować próbę nie tylko raz, ale wielokrotnie, i mieć nadzieję, że ostatecznie zasiane ziarno słowa przyniesie plon ${ }^{37}$. Jednocześnie Grzegorz zdawał sobie sprawę, że kwalifikacje duszpasterza, jego zaangażowanie, ofiarność, a nawet niemal heroiczna cierpliwość nie przyniosą oczekiwanego rezultatu, jeśli nie będzie odpowiedzi ze strony słuchaczy słowa Bożego ${ }^{38}$.

3. Zagrożenia w posłudze duszpasterskiej. Czas posługi biskupiej Grzegorza Teologa nie jest czasem idealnych duszpasterzy, bez reszty oddanych realizacji kapłańskiego powołania. Zdaniem biskupa Nazjanzu niewiele się w tym względzie zmieniło od czasów Starego Testamentu. Prorocy Starego Testamentu Izajasz, Micheasz, Malachiasz, Zachariasz, Ezechiel i Jeremiasz wypominali kapłanom Izraela niegodne postępowanie ${ }^{39}$. Ciągle największym zagrożeniem owocności posługi duszpasterza jest on sam, jego pycha, brak odpowiedzialnego podejścia do powierzonych obowiązków, chęć zdobycia władzy i popularności, a także dążenie do osiągnięcia korzyści materialnych. Niebezpieczeństwa te nie są wytworem wyobraźni Grzegorza, ale wynikiem obserwacji posługi wielu mu współczesnych kapłanów, którzy w swoim postępowaniu ulegli tym pokusom ${ }^{40}$. Przerażeniem napawał kaznodzieję widok kapłanów, którzy przystępują do sprawowania świętych misteriów i głoszenia

${ }^{35}$ Por. tamże 2, 52-55, PG 35, 461-465.

36 Tenże, Oratio 21, 31, PG 35, 1120, tłum. zbiorowe, w: Św. Grzegorz z Nazjanzu, Mowy wybrane, red. S. Kazikowski, Warszawa 1967, 240.

${ }^{37}$ Por. tenże, Oratio 32, 30, PG 36, 208. Zob. Wygralak, Grzegorza z Nazjanzu wizja kapłaństwa, s. 154.

${ }^{38}$ Por. Gregorius Nazianzenus, Oratio 2, 40-41, PG 35, 448-449.

${ }^{39}$ Por. tamże 2, 56-68, PG 35, 465-478. Refleksje proroków na temat postępowania kapłanów były przedmiotem rozważań wielu Ojców Kościoła, np. Grzegorza Wielkiego (Homilae in Evangelia 14 i 17). Najbardziej znanym tekstem jest kazanie św. Augustyna O Pasterzach (Sermo 46, PL 38, 295-316, tłum. A. Strzelecka: Augustyn z Hippony, ,, O pasterzach”. Kazanie 46. Na Ezechiela 34, 1-16, TPatr 8 (2011) 175-211). Villagómez, El sacerdocio en la Oratio II de Gregorio Nacianceno, s. 178-179.

${ }^{40}$ Por. Gregorius Nazianzenus, Oratio 2, 8, PG 35, 416. Zob. Wygralak, Grzegorza z Nazjanzu wizja kapłaństwa, s. 152. 
Ewangelii bez odpowiedniego przygotowania. Czynią to z myślą o własnych korzyściach, zupełnie lekceważąc fakt, że kiedyś będą musieli zdać rachunek ze swego postępowania ${ }^{41}$. Ta pycha i brak odpowiedzialności są wielkim zagrożeniem dla każdego duszpasterza. Przyjmując taką postawę nie będzie on nigdy autentycznym świadkiem głoszonej prawdy. Kolejnym niebezpieczeństwem jest chęć zdobycia sympatii wiernych w zamian za niejednoznaczną ocenę ich grzesznego postępowania. Grzegorz stwierdza w swojej mowie: „A złych i dobrych rozróżniamy nie na podstawie postępowania, lecz według naszych chęci lub kumoterstwa"42. Pasterze muszą również uważać, aby nie wykorzystywać swej pozycji społecznej do rozgrywania osobistych interesów i rozrachunków ${ }^{43}$. Niebezpieczeństwem jest również dążenie do szczytnych celów niegodnymi metodami. Należy mieć na uwadze, do czego wykorzystuje się imię samego Chrystusa ${ }^{44}$. Ponadto każdy kapłan musi liczyć się z siłą różnorakich pokus. Nie będzie umiał ich przezwyciężyć, jeśli nie podejmie walki. Grzegorz przypomina o niej pasterzom:

„Prowadzimy ją dzień i noc, czasem w ukryciu, czasem otwarcie, z powodu uległości ciała (por. Flp 3, 21), z powodu rozkoszy, jakie nam dają zmysły oraz wszelkie przyjemności tego życia, które nami rzucają w górę i na dół oraz kręcą na wszelkie strony; z powodu pyłu materii (por. Ps 39, 3), w którym utknęliśmy (Ps 68, 3); z powodu praw grzechu, które w nas zwalczają prawa ducha (por. Rz 7, 23), usiłując zniszczyć w nas królewski obraz i skalać strumyk Bożego życia, który dzięki Bogu wytrysnął w nas"45.

Ogromnym niebezpieczeństwem jest więc dla kapłana otaczający go świat, który wabi najróżniejszymi przyjemnościami prowadzącymi do grzechu. Biskup Nazjanzu ostrzega, iż każdy kto ulegnie powabom tego świata naraża się na utratę w sercu Bożego obrazu i na zejście z Bożej drogi życia.

Przemyślenia Grzegorza z Nazjanzu na temat realizacji powołania do kapłaństwa zdumiewają swoją aktualnością. Mówca stara się sprecyzować swoją wizję kapłaństwa podkreślając przede wszystkim rolę duchowej więzi duszpasterza z Bogiem. Głębia duchowego życia kapłana jest fundamentem całej jego pasterskiej działalności. I nie chodzi jedynie o wolność od grzechu. To zbyt mało. Kapłan musi być człowiekiem, który przez całe życie rozwija swoje życie wewnętrzne, rozwija cnoty, pogłębia swoją relację z Bogiem. To dzięki zaufaniu Bogu, jego posługa ma szansę przynieść dobre owoce.

\footnotetext{
${ }^{41}$ Por. Gregorius Nazianzenus, Oratio 2, 8, PG 35, 416.

${ }^{42}$ Tamże 2, 80, PG 35, 485, tłum. Szymusiak, s. 281.

${ }^{43}$ Por. tamże 2, 83, PG 35, 489.

${ }^{44}$ Por. tamże 2, 85-86, PG 35, 489-492.

${ }^{45}$ Tamże 2, 91, PG 35, 493, tłum. Szymusiak, s. 283.
} 
Dla Grzegorza jest oczywiste, że troska o rozwój duchowy zajmuje pierwsze miejsce w formacji kapłańskiej. Nie wolno jednak lekceważyć wiedzy, przede wszystkim teologicznej, niezbędnej do pracy w duszpasterstwie.

Tak przygotowany kapłan ma obowiązek głoszenia Ewangelii. Aby czynić to owocnie konieczna jest znajomość powierzonych sobie wiernych, ich wykształcenie, środowisko w którym żyją, stan ducha. W ten sposób Grzegorz wydaje się propagować bardziej indywidualne podejście duszpasterza do człowieka. Każdy pasterz podejmując posługę słowa powinien czynić to z zaangażowaniem, gorliwością, ale i cierpliwością. Należy wiernym, szczególnie tym, którzy pogubili się w swoim życiu, dawać kolejne szanse powrotu.

Biskup Nazjanzu, jako człowiek nie tylko wielkiego ducha, ale też realnego spojrzenia na świat, wskazuje także niebezpieczeństwa, które zagrażają duszpasterzom. Wymienia pychę, chęć rządzenia i wykorzystywania urzędu do własnych interesów oraz materializm.

\section{THE IMAGE OF THE PRIEST - PASTOR OF SOULS IN THE TEACHING OF ST. GREGORY OF NAZIANZUS}

\section{(Summary)}

The article presents the thoughts of St. Gregory of Nazianzus on the attitudes of priests in their pastoral work. The bases of this study are selected speeches and works of poetry by St. Gregory. The Bishop of Nazianzus indicates first and foremost the importance of the spiritual formation of each priest. Without reducing the importance of an intellectual formation, he puts the concern for the development of the inner life in the primary place. The deeply spiritual priest, having a thorough theological knowledge, can take up the mission of proclaiming God's word responsibly. The fruitfulness of this ministry also depends on the discernment of the spiritual, moral and intellectual state of the faithful, whom he is serving. St. Gregory also points out the dangers that threaten every priest. These are above all: pride, which leads to the desire to rule and not to serve, as well as materialism and the use of one's office to further one's own private interests.

Key words: Gregory of Nazianzus, priesthood, pastoral work, evangelisation.

Słowa kluczowe: Grzegorzz Nazjanzu, kapłaństwo, duszpasterstwo, ewangelizacja.

\section{BIBLIOGRAFIA:}

\section{Źródła}

Augustinus Hipponensis, De pastoribus (in Ezechiel XXXIV, 1-16), PL 38, 270-295, thum. A. Strzelecka: Augustyn z Hippony, „O pasterzach”. Kazanie 46. Na Ezechiela XXXIV, 1-16, TPatr 8 (2011) 175-211.

Gregorius Magnus, Homilae in Evangelia, PL 76, 1075-1312. 
Gregorius Magnus, Regula pastoralis, ed. F. Rommel, SCh 381-382, Paris 1992, tłum. E. Szwarcenberg-Czerny: Grzegorz Wielki, Księga reguly pasterskiej, Wstęp i oprac. M. Starowieyski, ŹM 30, Tyniec - Kraków 2003.

Gregorius Nazianzenus, De diversis vitae generibus (= Carmina II 1, 17), PG 37, $1262-$ 1269, tłum. J.M. Szymusiak, w: tenże, Grzegorz Teolog. U źródeł chrześcijańskiej myśli IV wieku, Poznań 1965, 514-516.

Gregorius Nazianzenus, De vita sua (= Carmina II 1, 11), PG 37, 1029-1166, thum. T. Sinko: Poemat autobiograficzny, w: J.M. Szymusiak, Grzegorz Teolog. U źródet chrześcijańskiej myśli IV wieku, Poznań, 1965, 469-510.

Gregorius Nazianzenus, Epistula 8, PG 37, 33-34, tłum. J. Stahr, w: Św. Grzegorz z Nazjanzu, Listy, POK 15, Poznań 1933, 14-15.

Gregorius Nazianzenus, Oratio 18, PG 35, 985-1044, tłum. J.M. Szymusiak, w: tenże, Grzegorz Teolog. Uźródeł chrześcijańskiej myśli IV wieku, Poznań 1965, 323-345.

Gregorius Nazianzenus, Oratio 2, PG 35, 408-513, thum. J.M. Szymusiak, w: tenże, Grzegorz Teolog. U źródet chrześcijańskiej myśli IV wieku, Poznań 1965, 257-290.

Gregorius Nazianzenus, Oratio 21, PG 35,1081-1128, tłum. zbiorowe, w: Święty Grzegorz z Nazjanzu, Mowy wybrane, red. S. Kazikowski, Warszawa 1967, 226-243.

Gregorius Nazianzenus, Oratio 32, PG 36, 173-212, tłum. zbiorowe, w: Święty Grzegorz z Nazjanzu, Mowy wybrane, red. S. Kazikowski, Warszawa 1967, 364-382.

\section{Opracowania}

Alvés Sousa P.G., El sacerdocio permanente en la „, Oratio II, Apologetica” de San Gregorio Nacianceno, w: Escritos sobre el carácter sacerdotal, Teología del Sacerdocio 6, Burgos 1974, 25-41.

Bernardi J., Saint Grégoire de Nazianze observateur du milieu ecclésiastique et théoricien de la fonction sacerdotale, w: Migne et le renouveau des études patristiques,éd. A. Mandouze, Paris 1985, 349-357.

De Halleux A., Grégoire de Nazianze témoin du caractère sacerdotal?, w; Festschrift J. Gribomont, Roma 1988, 331-347.

GAURIER F., La retraite et le sacerdoce chez Grégoire de Nazianze, Turnhout 2002.

Jourjon M., Le sacerdoce d'aprés l',,Oratio Secunda” de saint Grégoire de Nazianze, „Bulletin du Comité des Etudes. Compagnie de Saint-Sulpice” 38-39 (1962) 375-383.

SERra M., La carità pastorale in S. Gregorio Nazianzeno, OCP 21 (1955) 337-374.

Szymusiak J.M., Grzegorz Teolog. Uźródeł chrześcijańskiej myśli IV wieku, Poznań 1965.

Trisoglio F., Il pastore d'anima in San Gregorio di Nazianzo, „Renovatio” 25 (1990) 509527; 26 (1991) 11-36, 185-212, 345-271; 27 (1992) 11-18.

Villagómez F., El sacerdocio en la Oratio II de Gregorio Nacianceno, „Ecclesia” 26 (2012) fasc.2, 175-201.

Wygralak P., Grzegorza z Nazjanzu wizja kapłaństwa. Wprowadzenie do mowy: „, Własna apologia po powrocie z Pontu i rozprawa o kapłaństwie”, TPatr 11 (2014) 143-155. 
